

\title{
SISTEM AUDIT ISO 9001 : 2000 INTERNAL DAN EKSTERNAL PENDEKATAN PADA PENINGKATAN KEPUASAN PELANGGAN (STUDI KASUS PADA PT. MARGA MAJU JAYA)
}

Oleh : Munir Azhari*

email : munir.azhari@gmail.com

\begin{abstract}
Munir Azhari, ISO 9001:2000 Internal and External Audit System Approach to Improve Customer Satisfaction. Quality is an image which is very hungered for each. Every flexible pavement in giving service to customer, goodness in the case of product service and also service. Congeniality quality of in flexible pavement service industries context can be defined to through various approach, but in principle is reaching of according to among result of activity to be delivered by customers to service company.

ISO 9000 representing one of the management system quality of which is on this time become especial choice to flexible pavement service which wish to apply concept from management system quality of consistently and is systematic.

The company that has the ISO must commit that is all kind from the lower level until top management have to run the ISO system in right way. In this chase PT. Marga Maju Mandiri runs ISO system on the tract. The relationship between ISO 9001 : 2000 implementing with customer satisfaction can be see as the result such as repeat order, that is the customers have got the satisfaction. PT. Marga Maju Mandiri has been running the philosophy of the ISO 9001 : 2000 , they are; what you do you write, what you write you do, what you did you record and safety factor.

The implementation of the quality management concept that has been carried out properly and effectively through full commitment from the company management in service orientation at PT. Marga Maju Mapan will produce asphalt services whose quality is closer to meeting the satisfaction desired by customers in accordance with work standards and specifications.

keyword: Customer satisfaction, ISO 9001:2000, Internal and External Audit System.
\end{abstract}

\section{PENDAHULUAN}

\section{Latar Belakang Masalah}

Pengendalian mutu atau kualitas pelayanan merupakan salah satu kegiatan pelaksanaan PT. 3M (Marga Maju Mapan ) sebagai penyedia jasa Hotmix ( flexible pavement ) yang sangat penting dalam rangka mencapai sasaran pelayanan yang baik, khususnya yang menyangkut kepuasan pelanggan .

Secara lebih luas kontrol mutu pelayanan tidak hanya mencangkup pengawasan atau pengontrolan pada tahap pelaksanaan pekerjaan pengaspalan saja, tetapi juga mencangkup kegiatan pengontrolan pada saat perencanaan agregat untuk pembuatan aspal, pengujian laboratorium, pelaksanaan, sampai pada massa pemeliharaan umur aspal, hingga serah terima oleh pemakai jasa, dalam hal ini pihak Jasa Marga..

Kegiatan tersebut di atas perlu disadari oleh PT. $3 \mathrm{M}$ yang terlibat dalam proses pembuatan dan pelaksaan, hinggga masa pemeliharaan. Apabila terjadi keterlambatan, atau ketidak-sesuaian dengan hasil di lapangan terhadap waktu yang telah ditentukan, maka para pelaksana dan pengawas operasional dianggap sebagai penyebab utamanya.

\section{Identifikasi Masalah}

Bisnis jasa pengerjaan aspal belakangan ini semakin hari semakin menarik para penyedia jasa khususnya PT. 3M, karena mempunyai pasar yang sangat potensial dan tentunya banyak sekali permasalahan yang di hadapi seperti:

1. Sistem pendokumentasian yang sesuai dengan standar

2. Pelaksanaan safety factor sudah sejauh mana.

3. Prosedural audit yang memakan waktu lama

4. Peningkatan mutu pekerjaan yang berkesinambungan

5. Proses pengerjaan aspal sejak perencanaaan, implementasi hingga perawatan.

\footnotetext{
* Dosen Sekolah Tinggi Manajemen IMMI
} 


\section{Pembatasan Masalah}

Sebagai batasan masalah, peneliti hanya meninjau sejauh mana implementasi di lapangan oleh salah satu perusahaan yang begerak dibidang pengaspalan jalan yaitu PT.Marga Maju Mapan dalam penggunaan sistem audit secara internal dan eksternal ISO 9001 : 2000 di analisis melalui kepuasan pelanggan.

\section{Perumusan Masalah}

Pada penelitian ini, peneliti mengambil fokus terhadap penerapan sistem audit eksternal dan internal ISO 9001 : 2000 di PT.3M sehingga peneliti dapat merumuskan permasalahan apakah terdapat kepuasan pelanggan terhadap perusahaan yang menggunakan ISO $9001: 2000$.

\section{DESKRIPSI TEORITIS}

\section{HAKIKAT KEPUASAN PELANGGAN}

\section{Kepuasan Pelanggan}

Kita telah mengemukakan bahwa pembeli bergerak setelah membentuk persepsi terhadap nilai penawaran. Kepuasan Pelanggan sesudah pembelian tergantung dari kinerja penawaran dibandingkan dengan harapan. Berikut ini definisi tentang kepuasan pelanggan :

Kepuasan adalah tingkat perasaan seseorang setelah membandingkan kinerja (atau hasil) yang dia rasakan dibandingkan dengan harapannya. Jadi tingkat kepuasan adalah fungsi dari perbedaan antara kinerja yang dirasakan dengan harapan. Pelanggan dapat mengalami salah satu dari tiga tingkat kepuasaan yang umum. Kalau kinerja dibawah harapan, pelanggan kecewa. Kalau kinerja sesuai harapan, pelanggan puas. Kalau kinerja melebihi harapan, pelanggan sangat puas, senang atau gembira.

Banyak perusahaan berhasil yang menaikan harapan pembeli dan menghantarkan kinerja yang sesuai. Perusahaan ini menuju pada TCS $1 / 2$ Total Customer Satisfaction $1 / 2$ - Kepuasan Pelanggan Sepenuhnya. Akhirnya dasar filosofi operasi perusahaan adalah perusahaan berusaha memberikan tingkat kepuasan pelanggan yang tinggi, dan tetap memberikan tingkat kepuasan yang setidak-tidaknya dapat diterima oleh pihak lain yang berkepentingan dalam batasan sumber daya perusahaan.

\section{HAKIKAT SISTEM MANAJEMEN MUTU ISO 9000}

Sistem Manajemen Mutu ISO 9001

ISO ( The International Organization for Standardization ) adalah badan standar dunia yang dibentuk untuk meningkatkan perdagangan internasional yang berkaitan dengan perubahan barang dan jasa. ISO dapat disimpulkan sebagai koordinasi standar kerja internasional, publikasi standar harmonisasi internasional dan promosi pemakaian standar internasional.

ISO 9000 adalah suatu pedoman untuk mewujudkan Quality Assurance, sehingga ISO 9000 juga sering disebut Quality Assurance System. Bila Quality Control dibandingakan dengan Quality Assurance, akan tampak bahwa Quality Control adalah kegiatan dimana sesuatu sudah atau sedang terjadi, sementara Quality Assurance adalah kegiatan dimana sesuatu belum terjadi, jadi bersifat pencegahan.

Keuntungan yang bisa dirasakan dari implementasi ISO 9000, antara lain :

1) Membuat sistem kerja dalam suatu perusahaan menjadi standar kerja yang terdokumentasi

2) Dengan adanya ISO 9000, ada jaminan bahwa perusahaan itu mempunyai sistem manajemen mutu dan produk yang dihasilkan sesuai dengan keinginan pelanggan

3) Dapat berfungsi sebagai standar kerja untuk melatih karyawan baru

4) Menjamin bahwa proses yang dilaksanakan sesuai dengan sistem manajemen mutu yang ditetapkan

5) Semangat pegawai ditingkatkan karena mereka merasa adanya kejelasan kerja sehingga mereka bekerja dengan efisien

Hal-hal yang sering menjadi penghambat dalam penerapan sistem manajemen mutu antara lain :

1) Kurangnya komitmen

2) Kurangnya sumber daya

3) Kurangnya partisipasi

Untuk mengatasi hambatan dalam menerapkan sistem manjemen mutu (SMM) ini, dapat dilakukan hal-hal sebagai berikut :

1) Mangadakan infrastruktur untuk implementasi

2) Mangadakan pelatihan

3) Membuat indikator kerja

\section{Peranan Audit Sistem Manajemen Konstruksi Pengaspalan}

Untuk memastikan sistem manajemen mutu yang dilakukan efektif, penilaian secara objektif dan berkala perlu dilakukan. Dengan melakukan penilaian ini, organisasi akan mengetahui kondisi atau keadaannya saat ini. Audit yang objektif akan memberikan jaminan bahwa sistem manajemen mutu diterapkan dan dipelihara sesuai dengan kebijakan, sasaran dan rencana yang diterapkan. 
Hasil audit ini akan dijadikan bahan atau alat dalam melakukan tindakan koreksi/pencegahan yang mengarah pada peningkatan. Oleh karena itu, standar Internasional menekankan pentingya audit sebagai alat pemantau dan verifikasi. Audit sistem manajemen mutu memberikan beberapa keuntungan, antara lain :

1) Mampu mengembangkan sistem manajemen mutu terpadu yang efektif

2) Menyempurnakan proses pengambilan keputusan manajemen

3) Membantu pembagian sumber daya yang optimal

4) Memungkinkan tindakan koreksi tepat waktu

5) Meningkatkan produktivitas

6) Meningkatkan kepuasan konsumen

\section{Jenis Audit Sistem Manajemen Mutu}

Audit sistem mutu biasanya di lakukan untuk menentukan tingkat kesesuaian aktivitas perusahaan terhadap standar sistem mutu yang telah ditentukan serta efektivitas dari penerapan sistem tersebut. Jenis - jenis pembagian audit mutu berdasarkan pihak yang melaksanakan, dapat diuraikan sebagai berikut :

1) Audit Pihak Pertama (First Audit Party)

Kegiatan audit yang dilakukan oleh pihak pertama (perusahaan) secara internal menurut tata cara ISO 9000, untuk mengetahui keefektifan penerapan sistem mutu pada perusahaan tersebut dan dilakukan oleh staf yang telah dilatih (internal audit).

2) Audit Pihak Kedua (Second Party Audit) Kegiatan audit yang dilakukan oleh pihak kedua (klien) yang menerima hasil produk/jasa dari perusahaan (audit pelanggan).

3) Audit Pihak ketiga (Third party)

Kegiatan audit yang dilakukan oleh pihak ketiga (badan standar nasional atau internasioanl melalui badan sertifikasi),

\section{Tujuan Audit Sistem Manajemen Mutu}

1) Untuk Internal
a. Melihat kekurangan sistem manajemen mutu
b. Mengevaluasi kekurangan untuk kemudian melakukan tindakan koreksi
c. Menilai kesiapan untuk audit eksternal (pihak kedua atau pihak ketiga)

2) Untuk Eksternal
a. Memenuhi persyaratan standar sistem manajemen mutu
b. Memenuhi persyaratan badan sertifikasi
c. Memenuhi persayaratan pelanggaran (khusus dalam kontrak)

\section{Definisi Kualitas atau Mutu}

Mutu Menurut Standar ISO - 8402 (1986) adalah sifat dan karakteristik produk atau jasa yang membuatnya memenuhi kebutuhan pelanggan atau pemakai (customers). Mutu Menurut Standar ISO -9000 : 2000 adalah derajat atau tingkat karakteristik yang melekat pada produk yang mencukupi persyaratan. Mutu Menurut Building Research Establisment (BRE) adalah totalitas sifat dari suatu bangunan yang memungkinkan bangunan tersebut untuk memenuhi kebutuhan, termasuk cara dimana masing-masing sifat dikaitkan, diseimbangkan maupun digabungkan dalam keseluruhan bangunan dan keadaan lingkungannya. Mutu menurut Garvin (1998) adalah suatu kondisi dinamis yang berhubungan dengan produk, manusia (tenaga kerja), proses dan tugas, serta lingkungan yang memenuhi atau melebihi pelanggan atau konsumen. Pandangan atau pengertian mutu pada umumnya dihubungkan dengan harga yang tinggi, merk dagang suatu barang dan juga identik dengan kemewahan .

Tabel Perbedaan TQM dan QA

\begin{tabular}{|c|l|l|l|}
\hline No & \multicolumn{1}{|c|}{ Item } & \multicolumn{1}{c|}{ TQM } & Quality Assurance (QA) \\
\hline 1 & Titik berat kegiatan & Koordinasi & Deteksi kesalahan \\
\hline 2 & Metode & Process control & a-point-in-time-checking \\
\hline 3 & Karakteristik & Proaktif & Reaktif \\
\hline 4 & Tanggung jawab & $\begin{array}{l}\text { Seluruh unsur } \\
\text { dalam perusahaan }\end{array}$ & Hanya pihak inspeksi \\
\hline 5 & Orientasi & $\begin{array}{l}\text { Membangun } \\
\text { kualitas }\end{array}$ & Mengontrol kualitas \\
\hline 6 & Fokus & Keseluruhan proses & Hasil akhir \\
\hline
\end{tabular}

Tabel Perbedaan QA dan QC

\begin{tabular}{|l|l|l|l|}
\hline No & \multicolumn{1}{|c|}{ Item } & \multicolumn{1}{|c|}{$\begin{array}{c}\text { Jaminan Mutu } \\
(\mathbf{Q A})\end{array}$} & \multicolumn{1}{|c|}{ Kendali Mutu (QC) } \\
\hline 1 & Titik Berat kegiatan & $\begin{array}{l}\text { Pada proses dan } \\
\text { standar prosedur }\end{array}$ & $\begin{array}{l}\text { Pada produk (hasil) dan } \\
\text { standar produk }\end{array}$ \\
\hline 2 & Sasaran & $\begin{array}{l}\text { Terjaminnya } \\
\text { keandalan jalannya } \\
\text { pekerjaan }\end{array}$ & $\begin{array}{l}\text { Terjaminya keandalan } \\
\text { mutu hasil }\end{array}$ \\
\hline 3 & Bidang kendali & $\begin{array}{l}\text { Pada proses } \\
\text { administrasi }\end{array}$ & $\begin{array}{l}\text { Pada hasil yang sudah } \\
\text { dicapai (akhir) dan yang } \\
\text { sedang dalam pelaksanaan }\end{array}$ \\
\hline 4 & $\begin{array}{l}\text { Tolok ukur } \\
\text { Keberhasilan }\end{array}$ & $\begin{array}{l}\text { Dokumentasi tertib } \\
\text { dan tersimpan } \\
\text { dengan rapi }\end{array}$ & $\begin{array}{l}\text { Hasil (produk) sesuai } \\
\text { dengan persyaratan mutu } \\
\text { (spek teknis) }\end{array}$ \\
\hline
\end{tabular}

\section{Kerangka Berpikir}

Sebagai kerangka berpikir dari Analisis kepuasan pelanggan terhadap manajemen yang menerapkan manajemen kualitas ISO 9001 :

2000 dapat dilihat dari gambar dibawah ini : 
Gambar Model Proses Sistem Manajemen Kualitas ISO $9001: 2000$



\section{Hipotesa Penelitian}

Hipotesa penelitian ini adalah :

Diduga apabila penerapan dan pelaksanaan sistem manajemen mutu dalam hal ini fokus pada sistem audit secara internal dan eksternal dapat dilakukan sesuai komitmen manajemen dengan baik dan efektif, maka akan diperoleh hasil kerja atau produk yang bermutu baik berdasarkan persyaratan dan prosedur kerja yang telah ditentukan, sesuai dengan ISO 9001 : 2000 dapat memenuhi kepuasan pelanggan. 3

\section{METODOLOGI PENELITIAN Metode Penelitian}

Metode yang digunakan dalam penelitian ini bersifat deskriptif analisis (Descriptif research), maksudnya yaitu dari setiap sampel tersebut dapat dikumpulkan data-data yang diperlukan, kemudian dianalisa sehingga dapat disajikan dalam bentuk yang baik dan dikehendaki oleh peneliti.

Dalam menganalisa permasalahan pada penelitian ini, dilakukan beberapa langkah yang dianggap perlu dilakukan oleh peneliti. Langkah pertama adalah mencari informasi secara umum tentang mengapa dibutuhkan konsep penerapan sistem manajemen mutu pada pelaksanaan pengerjaan jalan aspal.

Selanjutnya melakukan studi dokumentasi atau studi kepustakaan untuk mencari penjelasan secara teoritis yang berhubungan dengan sistem manajemen mutu. Langkah yng kedua adalah mencari data-data yang dapat membuktikan bahwa sistem manajemen mutu pada pelaksanaan proses perencanaan untuk pengaspalan telah disosialisakan dan diterapkan pada PT. MARGA MAJU MAPAN . Kemudian data-data tersebut dianalisa dan dievaluasi, apakah komitmen manajemen dan konsekuensinya terhadap penerapan konsep manajemen mutu pada perusahaan pengaspalan tersebut telah berlangsung secara efektif dan efisien.

\section{Instrumen Penelitian}

Pengumpulan data merupakan prosedur yang sistematik dengan memperhatikan aturan yang telah ditentukan. Hal ini dimaksudkan utuk menghindari data yang tidak terpakai karena jauhnya informasi yang diperoleh dengan keperluannya. Data selalu ada hubungannya antara metode pengumpulan data dengan masalah penelitian yang hendak dipecahkan. Tidak jarang terjadi, masalah yang dirumuskan tidak mendapatkan pemecahan, dikarenakan hal-hal sebagai berikut :

1) Metode pengumpulan data tidak memungkinkan untuk menghasilkan data yang diperlukan, karena kesalahan dalam penarikan metode yang dipakai

2) Instrumen yang dipersiapkan meleset dari permasalahannya, karena kurangnya penguasaan teori meskipun telah banyak data terkumpul

3) Survei lapangan atau lokasi sebelum persiapan perencanaan penelitian tidak menghasilkan data yang akurat sebagai akibat lokasi tidak sesuai untuk ditunjuk dalam memberikan informasi

4) Kurangnya keterampilan pengumpulan data

Secara umum metode pengumpulan data dapat dibagi atas beberapa jenis, yaitu

1) Metode wawancara atau metode pengajuan pertanyaan langsung

2) Metode angket (kuisioner) atau metode pertanyaan secara tidak langsung

3) Metode observasi atau metode pengamatan

\section{PEMBAhaSAN HASIL PENELITIAN \\ Deskripsi Data}

Dalam penelitian ini, penyajian data hasil penelitian pada bagian ini berisikan tujuan terhadap system audit internal dan eksternal manajemen mutu yang diterapkan oleh pelaksanaan jasa konstruksi dalam hal ini pengaspalan. Sebagai data untuk tinjauan, dilakukan terhadap perusahaan penyedia jasa pengaspalan yang telah dilaksanakan oleh PT. 3M

Untuk tinjauan tersebut, yang dilakukan oleh peneliti adalah melakukan wawancara langsung ke lapangan dengan tujuan yang diharapkan oleh peneliti untuk mengetahui sejauh mana nilai efektivitas penerapan manajemen mutu yang telah diimplementasikan oleh perusahaan tersebut guna 
memberikan palayanan terbaik sehingga membuat pelanggan menjadi nyaman, puas dan tidak ingin pindah mencari perusahaan penyedia jasa pengaspalan yang lainnya.

\section{Pengujian dan Penjabaran Hipotesis}

1. Sistem Manajemen Mutu

Manual mutu ini menggambarkan Sistem Manajemen Mutu yang diterapkan oleh PT.3M yang mencangkup proses pemcanaan, pelakasaanaan, monitoring, perwatan hingga serah terima.

\section{a. Pedoman Mutu}

Sistem Manajemen Mutu mentrasformasikan kebijakan mutu, janji / komitmen manajemen, dan menggambarkannya dalam petunjuk untuk mencapai sasaran mutu, memenuhi persyaratan pelanggan dan mencari kepuasan pelanggan.

Membuat Prosedur seperti Prosedur penjemputan barang, pengiriman barang, pemasaran yang menjelaskan aktivitas dan tanggung jawab untuk semua proses kerja dalam operasional. Prosedur - prosedur ini menerapkan sistem mutu kedalam operasional penyedia jasa pengaspalan.

b. Pengendalian Dokumen

Semua dokumen ditinjau dan disetujui oleh personil yang berwenang. Prosedur dibuat untuk menjamin efektivitas pengendalian dokumen yang digunakan oleh setiap pemakai dalam status revisi yang berlaku. Pembuat dokumen menyimpan Daftar Dokumen Terkendali dari semua terbitan yang berlaku dan terbitan pengganti untuk distribusi yang telah ditentukan. Semua dokumen asli ditinjau dan disetujui sebelum diterbikan oleh origator dokumen. Semua revisi dicatat, revisi sebelumnya dimusnahkan dan dokumen asli yang disetujui disimpan sebagai arsip.

\section{Pembahasan / Analisis Secara Kualitatif Sasaran Mutu Bagian : Marketing}

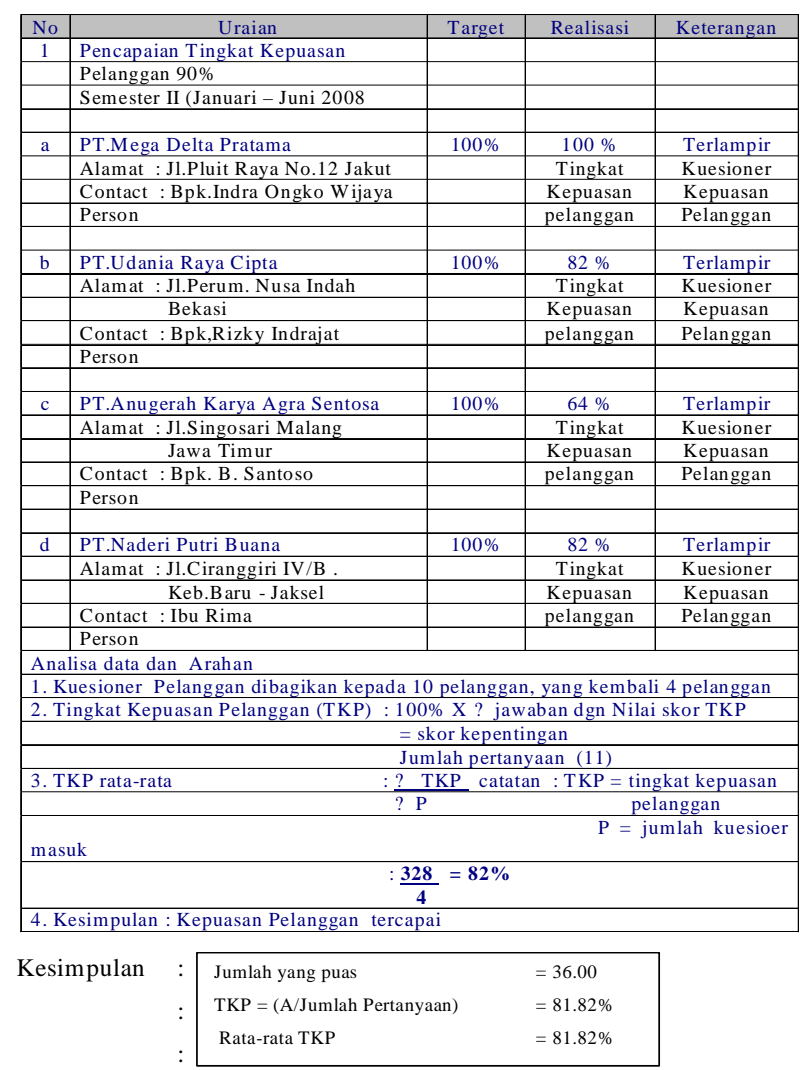

Tabel Kebijakan Mutu ISO 9001 : 2000 PT.Marga Maju Mapan, meliputi ; Detail dapat diilihat pada lampiran.

\begin{tabular}{|c|c|c|}
\hline No & Nama Perusahaan & Kebijakan Mutu \\
\hline 1 & PT.Marga Maju Mapan & $\begin{array}{l}\text { - Kebijakan Mutu: } \\
\text { Manajemen bertekad untuk bekerja tepat waktu dengan mutu yang baik untuk mencapai kepuasan pelanggan melalui } \\
\text { penerapan Sistem Manajemen Mutu ISO } 9001: 2000 \text { dan berusaha untuk meingkat inovasi produk dan Sumber Daya } \\
\text { Manusia secara berkelanjutan } \\
\text { - Sasaran Mutu: } \\
\text { Bagian Administrasi } \\
\text { 1. Administrasi \& Umum } \\
\text { - Penertiban dan perapihan surat menyurat tiap bulan } \\
\text { - Penertiban dan perapihan pengarsipan tiap bulan } \\
\text { - Perijinan, setifikat, tanda keanggotaan assosiasi diperbarui setiap tahun } \\
\text { 2. Marketing } \\
\text { - Pencapaian tingkat kepuasan pelanggan } 100 \% \\
\text { - Lulus prakualifikasi } 90 \% \text { per tahun } \\
\text { - Target penjualan } 30 \text { milyar rupiah pertahun } \\
\text { - Peningkatan } 20 \% \text { konsumen baru untuk meningkatkan omzet penjualan } \\
\text { Personalia } \\
\text { - Pelatihan untuk pemenuhan kompetensi keahlian untuk } 1 \text { orang selamal bulan pertahun } \\
\text { - Komputer - aplikasi perkantoran (Ms-office) } \\
\text { - Pealisasi program pelatihan } 80 \% \\
\text { - Peningkatan kesehjateraan karyawan (kenaikan gaji berkala) minimum } 10 \% \text { setiap tahun } \\
\text { - Pengarsipan data karyawan } 100 \%\end{array}$ \\
\hline
\end{tabular}




\begin{tabular}{|c|c|c|}
\hline No & Nama Perusahaan & Kebijakan Mutu \\
\hline & &  \\
\hline & & $\begin{array}{l}\text { 1. Perencanaan \& Evaluasi } \\
\text { - Addendum dalam tiap proyek maksimal } 2 \text { kali per proyek } \\
\text { - Pembuatan dokumen tender dilakukan oleh tim yang dibentuk dari bagian Teknik. Adm \& Keu, Marketing } \\
\text { - } \text { dan personalia sekurang-kurangnya masing-masing } 1 \text { orang } \\
\text { - Mekatihan untuk pemenuhan komptensi keahlian untuk } 1 \text { orang selama } 1 \text { bulan prtahun } \\
\text { - } \quad \text { Autocad } \\
\text { - Estimator } \\
\text { - Aplikasi pelatihan } 80 \% \\
\text { 2. Quality Control } \\
\text { - Kesesuaian material yang diuji pada Lembaga Independen } 90 \% \\
\text { - Pelaksanaan pemantauan QC proyek } 80 \% \text { dari jadwal } \\
\text { - Pengujian hasil konstruksi 100\% } \\
\quad \text { - Gelar Hotmix sesuai satuan } \\
\quad \text { - Kepadatan sesuai spesifikasi } \\
\text { - Retebalan sesuai spesifikasi } \\
\text { 3. Project Manager } \\
\text { - Ketersediaan tenaga kerja per proyek } 90 \% \\
\text { - Faktor lost material maksimum } 5 \% \\
\text { - Penyelesaian keluhan owner paling lambat } 2 \text { X } 24 \text { jam (tol) } \\
\quad \text { Penyelesaian keluhan owner paling lambat } 1 \text { minggu (bukan tol) }\end{array}$ \\
\hline
\end{tabular}

\section{KESIMPULAN DAN SARAN}

Berdasarkan penelitian yang penulis lakukan, maka dapat diambil kesimpulan :

1. Bahwa suatu perusahaan yang menjalankan ISO harus mempunyai komitmen yang berarti bahwa semua lini mulai dari yang terendah sampai dengan top management harus menjalankan sistem ISO itu sendiri secara benar.

2. Hubungan antara Penerapan ISO 9001:2000 dengan kepuasan pelanggan terlihat seperti adanya repeat order (pemesanan secara berkesinambungan ) artinya adalah Pelanggan puas dengan sistem yang dijalankan oleh PT.Marga Maju Mapan
3. PT.Marga Maju Mapan telah melaksanakan filosofi ISO 9001: 2000 secara benar yaitu what you do you write, what you write you do, what you did you record, and safety factor is number one.

4. Penerapan konsep manajemen mutu yang telah dilakukan secara baik dan efektif dengan penuh komitmen dari pihak manajemen perusahaan didalam orientasi pelayanan pada PT.Marga Maju Mapan akan menghasilkan pelayanan jasa asphalt yang mutunya lebih dekat untuk memenuhi kepuasan yang diinginkan oleh pelanggan sesuai dengan standar dan spesifikasi kerja. 


\section{Saran - Saran}

1. Untuk memperoleh hasil analisa data yang lebih valid dan akurat, maka apabila diadakan penelitian lebih lanjut untuk disempurnakan sebaiknya PT.Marga Maju Mapan melaksanakan survei terhadap kepuasan pelanggan secara langsung secara simultan dan berkesinambungan..

2. PT.Marga Maju Mapan sebaiknya lebih meningkatkan pengawasan terhadap penerapan ISO 9001 : 2000 khususnya di bagian operasional.

3. Sebaiknya setiap melakukan pekerjaan dilakukan breafing safety factor terlebih dahulu

\section{DAFTAR PUSTAKA}

Ariani, Wahyu, Dorothea. 1/2Manajemen Kualitas $1 / 2$. Penerbit Universitas ATMA JAYA Yogyakarta, Yogyakarta 1999

Hasan, Iqbal M. 1/2 Pokok - pokok Materi Metodologi Penelitian \& Aplikasinya 1/2, Penerbit Ghalia Indonesia , Jakarta 2002.

Kotler, Philip. 1/2Manajemen Pemasaran $1 / 2$, Penerbit Salemba Empat, Jakarta 1995
Kusnadi Moeljanto, Hadi. 1/2 Sistem Mutu ISO 9000 Bidang Pengairan 1/2, Departemen Pemukiman dan Prasarana Wilayah Edisi ke -3 , Jakarta.

Mizuno, Shigeru. 1/2 Pengendalian Mutu Perusahaan $1 / 2$, PT.Pustaka Binaman Pressindo, Jakarta, 1994.

Nasution, M.N. 1/2 Manajemen Mutu Terpadu (Total Quality Management) $1 \frac{1}{2}$, Penerbit Ghalia Indonesia, Jakarta, 2001.

Suardi, Rudi. 1/2 Sistem Manajemen Mutu ISO 9000 : 2000 Penerapannya Untuk Mencapai TQM1/2, Penerbit PPM, Jakarta, 2003.

Subiyanto, Ibnu. 1/2 Metodologi Penelitian 1/2, Universitas Gunadarma, Jakarta, 1993.

Soeharto, Iman. 1/2 Manajemen Proyek Dari Konseptual sampai dengan Operasional $1 / 2$, Penerbit Erlangga, Jakarta, 1997.

Tim Dosen LP3I. 1/2 Metodologi Penelitian Ilmiah Cara Praktis \& Sistematis Dalam Menuangkan Gagasan $1 / 2$, Penerbit Fajar, Jakarta, 1999. 
